\title{
Influence of Inoculum Concentration on Production of Spermogonia and Aecia on Pine Seedlings Infected by Basidiospores of Cronartium quercuum f. sp. fusiforme
}

\author{
R. A. Schmidt and T. Miller, School of Forest Resources and Conservation, Institute of Food and Agricultural Sci- \\ ences, University of Florida, Gainesville 32611-0410
}

\begin{abstract}
Schmidt, R. A., and Miller, T. 1999. Influence of inoculum concentration on production of spermogonia and aecia on pine seedlings infected by basidiospores of Cronartium quercuum $\mathrm{f}$. sp. fusiforme. Plant Dis. 83:367-370.

Seedlings of slash pine and loblolly pine inoculated with four concentrations of basidiospores of Cronartium quercuum $\mathrm{f}$. sp. fusiforme and exhibiting large galls ( $\geq 25 \mathrm{~mm}$ long) were observed for spermogonial and aecial sporulation. Basidiospores from a genetically heterogeneous source at 50,100,1,000 and 5,000 spores/5- $\mu$ l droplet were applied to the severed, succulent terminal of 6-week-old seedlings. Incidence of sporulation showing (i) spermatia (pycniospores) only, (ii) aeciospores only, (iii) spermatia and aeciospores, and (iv) absence of sporulation was recorded for 3 years. On slash pine, the percentage of seedlings showing only spermatia varied significantly and inversely with inoculum concentration. In contrast, the percentage of seedlings showing only aeciospores or aeciospores and spermatia varied directly with inoculum concentration. Results on loblolly pine were similar. It is suggested that, at low inoculum concentrations, hyphal anastomoses are limited by fewer haploid mycelia in infected tissues or fewer mating types resulting from incompatible host-parasite interactions.
\end{abstract}

Additional keywords: heterothallic, homothallic, hyphal anastomoses, Pinus elliottii var. elliottii, P. taeda, pycniospore

Cronartium quercuum (Berk.) Miyabe ex Shirai f. sp. fusiforme is a heteroecious, macrocyclic fungus whose uredinial hosts are Quercus spp. (red oak group). The aecial hosts are pines native to the southern United States, mainly slash pine (Pinus elliottii Engelm. var. elliottii), loblolly pine $(P$. taeda L.), and longleaf pine ( $P$. palustris Mill.). The disease, fusiform rust, is highly destructive on commercially important slash and loblolly pines $(1,24)$.

Although the disease has been studied intensively for 40 years, the mechanism or mechanisms of dikaryotization in the life cycle of $C$. quercuum $\mathrm{f}$. sp. fusiforme are not well understood. It is generally accepted that, because the spermogonia of $C$. quercuum $\mathrm{f}$. sp. fusiforme produce spermatia in an insect-attractive exudate, the spermatia function in dikaryotization (cross-fertilization) as originally described by Craigie $(6,7)$ for Puccinia helianthi Schwein., $P$. graminis Pers., and other species in the Uredinales. However, such spermatial function has not been demon-

Corresponding author: R. A. Schmidt

E-mail: rasch@gnv.ifas.ufl.edu

Contribution \#R-06045 of the Florida Agricultural Experiment Station.

Accepted for Publication 5 January 1999.

Publication no. D-1999-0204-01R

(C) 1999 The American Phytopathological Society strated conclusively for $C$. quercuum $\mathrm{f}$. $\mathrm{sp}$. fusiforme.

Hirt (11), in his extensive study of Cronartium ribicola J. C. Fisch. ex Rabenh., could not demonstrate a function for spermatia in the production of binucleate aeciospores, nor could he conclude that $C$. ribicola was heterothallic. He did state, "Binucleate aeciospores result from fusions of cells in the basal area of young aecia. Vegetative hyphae remain uninucleate." Like $C$. ribicola, $C$. quercuum $\mathrm{f}$. sp. fusiforme hyphae in pine hosts apparently remain uninucleate and produce binucleate aeciospores periodically (T. Miller, unpublished).

Spermogonia of $C$. quercuum f. sp. fusiforme, which conform to type No. 9 as described by Hiratsuka and Cummins (10), with sporogenous cells, spermatium initials, and spermatia, are produced on fusiform rust galls (22). The authors did not observe spermatization. The spermogonia are produced from mononucleate hyphae growing in the host tissues. The spermogonia may be followed by dikaryotic aeciospores, which typically are produced in the same area of the gall. The sporulation on fusiform rust galls on slash and loblolly pines may be spermogonia only, spermogonia followed by aecia, or aecia and aeciospores only (13).

Kuhlman (13), observing aecial sporulation on live galls in plantations of loblolly and slash pines in North and South Carolina, reported the average percentage of galls that produced aeciospores during four seasons ranged from 44 to $76 \%$. Galls that produced only spermogonia ranged from 3 to $19 \%$ over 3 years. In a similar study of fusiform rust galls in three slash pine plantations in northern Florida and southern Georgia, Chappelka et al. (5) recorded aeciospore production on 347 galls over 4 years. The greatest proportion of the galls (51\%) produced aeciospores consecutively for at least 2 years, $11 \%$ produced aeciospores every year, $4 \%$ every other year, $25 \%$ only once in 4 years, and $18 \%$ never produced aeciospores. The phenology of aecial sporulation was related to average minimum January temperatures (4). Kuhlman and Matthews (16) reported that spermatial and aecial sporulation was affected by pine host and inoculum source in slash and loblolly pine.

Buller (3) proposed five methods by which dikaryotization may occur in the rust fungi. In C. quercuum f. sp. fusiforme, two of these methods seem most probable: (i) fusion of compatible hyphae in the host tissues or (ii) classical spermatization as described by Craigie (6). Another method described by Buller, "annual self-diploidsation in rusts having systemic mycelium," is of interest here because $C$. quercuum f. sp. fusiforme and other tree rusts (e.g., C. ribicola) produce aeciospores annually from perennial mycelium in the pine host. Evidence for heterothallism is provided by genetic recombination studies $(8,26)$.

Much research on fusiform rust over the past 25 years has included 6-week-old seedlings of slash and loblolly pines inoculated with aqueous basidiospore suspensions $(2,19)$. We developed a technique for inoculating 6-week-old seedlings of slash and loblolly pines by severing the upper $\approx 1 \mathrm{~cm}$ of the succulent stem apex and applying a suspension of basidiospores to the wound (20). The success of this technique prompted a study to assess the effect of basidiospore inoculum concentrations on host response and sporulation using this wound technique (25).

The objectives of this research were to determine (i) if spermogonia and aecia would be produced on the wound-inoculated seedlings and (ii) if the concentrations of basidiospore inocula would affect the incidence of spermogonia and aecia. Also, we hoped to learn more about the mechanism or mechanisms of dikaryotization in the life cycle of $C$. quercuum $\mathrm{f}$. sp. fusiforme. 


\section{MATERIALS AND METHODS}

Pine seedlings. Seedling progeny of six slash pine and six loblolly pine families were inoculated through wounds with four concentrations of basidiospores of $C$. quercuum f. sp. fusiforme at the Resistance Screening Center (RSC), United States Forest Service, Asheville, North Carolina. Except for one control-pollinated slash pine family, seedlings were from openpollinated female parents (family) selected in Florida, North Carolina, South Carolina, Georgia, Alabama, and Mississippi. Families were previously tested for resistance to C. quercuum $\mathrm{f}$. sp. fusiforme in field progeny tests and greenhouse studies. Resistance in greenhouse tests refers to the relative proportion of seedlings with galls 9 months after inoculation with a genetically, and presumably pathogenically, diverse inoculum. For example, a resistant family may have 5 to $30 \%$ of its progeny infected; of these, some seedlings will have large galls ( $\geq 25 \mathrm{~mm}$ long) and others will have small galls $(<25 \mathrm{~mm}$ long). Gall size is a host reaction type and most seedlings with small galls (resistant reaction type) will remain this type: a few seedlings with small galls will develop large galls (susceptible reaction type) after 1 to 3 years.

Inoculations. The greenhouse tests at the RSC included four treatments: 50, 100, 1,000, and 5,000 basidiospores/seedling (inoculation concentrations; IC) applied in 5 - $\mu \mathrm{l}$ droplets to wounds made by severing the succulent terminal leader on 6-weekold seedlings. A total of 80 seedlings/species/family/IC were inoculated. Basidiospore IC were determined by Coulter Counter replicated counts for the 5,000 and 1,000 IC. The 50- and 100-IC droplets were counted with a microscope and averaged 53 and 103 basidiospores/5$\mu \mathrm{l}$ droplet for slash pine and 46 and 99 basidiospores $/ 5-\mu$ droplet for loblolly pine.
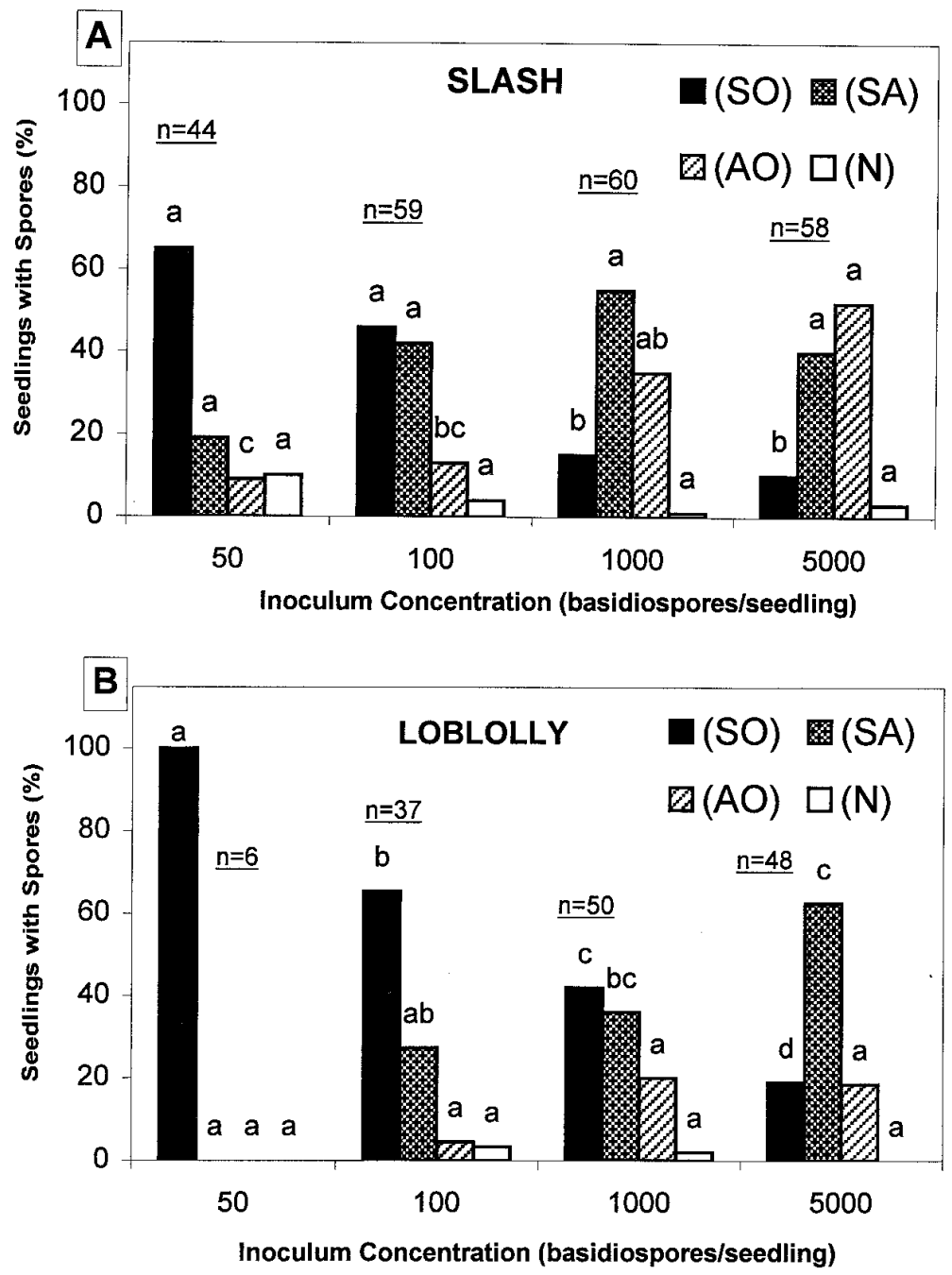

Fig. 1. The effect of inoculum concentration on the cumulative (age 2 to 4 years) percentage of (A) slash and (B) loblolly pine seedlings with large (>25 mm long) rust galls that sporulated in a greenhouse in Gainesville, Florida: spermatia only $=\mathrm{SO}$; spermatia and aeciospores $=\mathrm{SA}$; aeciospores only $=\mathrm{AO}$; and no sporulation $=\mathrm{N}$. Within sporulation classes, dissimilar lower case letters indicate that the percentage of seedlings sporulating differed significantly $(P=0.05) ; \mathrm{n}=$ number of seedlings for each inoculum concentration.

Basidiospores were obtained by inoculating red oak (Querca rubra L.) leaves with a 30-gall mixture of aeciospores collected from each of the two pine species in north Florida. Each pine species was inoculated with the inocula collected from that species. Mixed-gall inocula are known to be quite variable in pathogenicity, presumably containing many pathotypes $(17,23)$.

Experimental design and analyses. At 9 months after inoculation, 10 seedlings/family/IC with large rust galls (susceptible reaction type) were randomly selected to record sporulation. In several families, primarily at the lower IC (50 spores/seedling), fewer than 10 infected trees with "large" galls were available. Incidence of sporulation showing (i) spermatia only, (ii) aeciospores only, (iii) spermatia and aeciospores, (not necessarily in the same year), and (iv) absence of sporulation was recorded each week during the spore production periods for 3 years. Cumulative percentages of seedlings with spores during the 3 years were analyzed following an arcsine transformation of the data. The amount of sporulation was not quantified. Data were examined with analysis of variance (SAS Institute, Cary, NC) with Bonferonni means separation (21) and correlation analysis. Family differences within species were not significant; family data within species were pooled to examine the effects of IC on sporulation.

\section{RESULTS}

The incidence of sporulation in slash pine was related to IC as shown by the cumulative 3-year data (Fig 1A). The percentage of seedlings with spermatia only (SO) varied significantly and inversely with IC. In contrast, the percentage of seedlings with aeciospores only (AO) and spermatia and aeciospores (SA) both varied directly with IC. The percentage of seedlings which did not produce spermatia or aeciospores $(\mathrm{N})$ ranged from 3 to $7 \%$ among ICs.

Results on loblolly pine were similar to those on slash pine (Fig. 1B). Only six seedlings were available at the 50 IC. The incidence of SO decreased significantly with increasing IC. The percentage of seedlings with $\mathrm{AO}$ and SA increased significantly as IC increased. The percentage of seedlings which did not produce spores ranged from 0 to $3 \%$ among ICs. For both pine species, dates of spermatial (November to December) and aecial (March to April) sporulation were typical of those occurring in the field in Florida.

\section{DISCUSSION}

There are numerous reports of $C$. quercuum $\mathrm{f}$. sp. fusiforme basidiospore IC affecting the percentage infection of slash and loblolly pines $(9,15,18)$. Kuhlman (12) reported effects of temperature, light, and host response on the occurrence of sper- 
matia of $C$. quercuum $\mathrm{f}$. sp. fusiforme. We found no reports of basidiospore IC affecting the incidence of spermatial or aecial sporulation in this or similar rust pathosystems.

Our results raise several questions. Why was sporulation of $C$. quercuum f. sp. fusiforme on slash and loblolly pine galls significantly related to the concentration of basidiospores which initiated the galls, all of which were large and well-developed? Specifically, why were the percentages of pine seedlings with only spermatia inversely related to increasing IC? And, conversely, why were the percentages of pine seedlings with galls producing only aeciospores, or spermatia and aeciospores, directly related to increasing IC?

It may be assumed that, at the lower IC, fewer successful infections occurred which could limit, initially, the amount of haploid mycelium and increase spatial separation between the haploid mycelia in the infected tissue, decrease the number of compatible mating types, or both. Host-pathogen specialization $(8,26,27)$ could also play a significant role in limiting the number of infections, especially at low ICs of a pathogenically variable inoculum. In either case, dikaryotization by hyphal anastomoses or spermatization would likely be reduced or eliminated, resulting in spermogonia but no aecia.

Seedlings with large galls were selected and were observed for 3 years, during which time galls enlarged greatly and, presumably, haploid mycelium proliferated; thus, ample opportunity for dikaryotization (either by hyphal anastomosis or spermatization) should have occurred. Therefore, the preponderance of spermogonia and lack of aecia at the lower inoculum concentrations suggest a lack of compatible mating types, perhaps resulting from host-pathogen specialization.

Conversely, at the higher inoculum concentrations, assuming greater numbers of haploid mycelia in pine tissues, the increased probability of contact among compatible mating types (either by hyphal anastomosis or subsequent spermatization) would result in dikaryotization and formation of aecia or spermogonia and aecia. Although our data at high inoculum concentrations indicate that aecia formed frequently, with or without spermogonia, we did not examine the galls histologically and cannot say with certainty that subepidermal spermogonia were lacking. If spermogonia were lacking at the higher inoculum concentrations, dikaryotization could have occurred via hyphal anastomosis of compatible mating types and the spermogonial stage may have been bypassed. Kuhlman (14) reported aecia without spermatia in field studies as well as spermatia only and spermatia and aecia. Chappelka et al. (5) reported from field studies of 347 galls that $18 \%$ did not produce aeciospores during a 4-year period.
The failure of a high percentage of seedlings inoculated with low numbers of basidiospores to produce aecia during 3 years, despite producing abundant spermogonia in the presence of other seedlings with abundant spermogonia on the same greenhouse bench, suggests that crossspermatization was not frequent in the greenhouse environment. It is likely that this occurred because of a lack of spermatizing agents (e.g., insects) in the greenhouse. However, limited mating types at low ICs cannot be eliminated as the cause for lack of aecia, even if insects were present.

Doudrick et al. (8) used DNA markers to show that gametothalli (mycelia derived from single basidiospores) could be associated with spermatia droplets produced on pine galls, resulting from inoculation with the gametothalli. The authors further showed that spermatia from the same or different galls could be different fungal genotypes and the galls different phenotypes (i.e., galls containing different fungal genotypes). Our results do not provide conclusive evidence for the mechanism of dikaryotization in C. quercuum f. sp. fusiforme. However, indirectly, our results suggest the presence of mating types and the possibility of hyphal anastomoses as a mechanism of dikaryotization. Further, we suggest that these results may be related to host-pathogen specialization because, at low IC, resistant families may preclude many or most fungal genotypes. Using DNA markers, it may be possible to better understand the effect of inoculum concentration on sporulation and perhaps gain knowledge of the biology of $C$. quercuum f. sp. fusiforme. Wounded pine seedlings inoculated with single-spore derived mycelia are under study and may aid our understanding of the biology of $C$. quercuum f. sp. fusiforme.

\section{ACKNOWLEDGMENTS}

We thank J. English, W. Lante, and D. Wilson (School of Forest Resources and Conservation), and C. Young (Resistance Screening Center) for technical help; and the forest industry (Partnership for Fundamental Research in Forest Biology) for financial support.

\section{LITERATURE CITED}

1. Anderson, R. L., McClure, J. P., Cost, N., and Uhler, R. L. 1986. Estimating fusiform rust losses in five southeast states. South. J. Appl. For. 10:237-240.

2. Anderson, R. L., Young, C. H., Triplett, J., and Knighten, J. 1982. Resistance Screening Center procedures manual: A step-by-step guide to materials and methods used in operational screening of southern pines for resistance to fusiform rust. U.S. Dep. Agric. For. Serv. For. Pest Manage. Rep. No. 82-118.

3. Buller, A. H. R. 1950. Pages 266-288 in: Researches on Fungi. Vol. VII. Royal Soc. Can. Univ. Toronto Press.

4. Chappelka, A. H. III, and Schmidt, R. A. 1983. The phenology of inoculum production by Cronartium quercuum $\mathrm{f}$. sp. fusiforme on slash pine in north Florida and south Georgia.
For. Sci. 29:253-262.

5. Chappelka, A. H. III, Schmidt, R. A., and Patterson, H. D. 1984. Dynamics of aeciospore inoculum production of Cronartium quercuum f. sp. fusiforme on slash pine. For. Sci. 30:787-792.

6. Craigie, J. H. 1927. Discovery of the function of the pycnia of the rust fungus. Nature 120:765-767.

7. Craigie, J. H. 1933. Union of pycniospores and haploid hyphae of Puccinia helianthi (Schw.) Nature 131:25.

8. Doudrick, R. L., Nance, W. L., Nelson, C. D., Snow, G. A., and Hamelin, R. C. 1993. Detection of DNA polymorphisms in a single urediniospore-derived culture of Cronartium quercuum f. sp. fusiforme. Phytopathology 83:388-392.

9. Griggs, M. M., Dinus, R. J., and Snow, G. A. 1984. Inoculum source and density influence assessment of fusiform rust resistance in slash pine. Plant Dis. 68:770-774.

10. Hiratsuka, Y., and Cummins, G. B. 1963 Morphology of spermogonia of the rust fungi. Mycologia 55:487-507.

11. Hirt, R. R. 1964. Cronartium ribicola: Its growth and reproduction in the tissues of eastern white pine. Tech. Pub. No. 86. State Univ. Coll. For. Syracuse Univ.

12. Kuhlman, E. G. 1981. Environmental and host susceptibility affect spermatia formation by Cronartium quercuum f. sp. fusiforme. (Abstr.) Phytopathology 71:233.

13. Kuhlman, E. G. 1981. Sporulation by Cronartium quercuum f. sp. fusiforme on loblolly and slash pine. Phytopathology 71:345-347.

14. Kuhlman, E. G. 1992. Interaction of virulent single-gall rust isolates of Cronartium quercuum $\mathrm{f}$. sp. fusiforme and resistant families of loblolly pine. For. Sci. 38:641-651.

15. Kuhlman, E. G., Amerson, H. V., Jordan, A. P., and Pepper, J. O. 1997. Inoculum density and expression of major gene resistance to fusiform rust disease in loblolly pine. Plant Dis. 81:597-600.

16. Kuhlman, E. G., and Matthews, F. R. 1985. Pine host and rust source affect sporulation of Cronartium quercuum f. sp. fusiforme. Pages 259-270 in: Proc. Int. Union For. Res. Org. Work. Group. Rust of hard pines. Athens, GA.

17. Kuhlman, E. G., and Matthews, F. R. 1993. Variation in virulence among single-aeciospore isolates from single-gall isolates of Cronartium quercuum $\mathrm{f}$. sp. fusiforme. Can. J. For. Res. 23:67-71.

18. Matthews, F. R., Miller, T., and Dwinell, L. D. 1978. Inoculum density: its effect on infection by Cronartium fusiforme on seedlings of slash and loblolly pine. Plant Dis. Rep. 62:105-108.

19. Matthews, F. R., and Rowan, S. J. 1972. An improved method for large-scale inoculations of pine and oak with Cronartium fusiforme. Plant Dis. Rep. 56:931-934.

20. Miller, T., and Schmidt, R. A. 1994. Infection of slash and loblolly pine seedlings by basidiospores of Cronartium quercuum $\mathrm{f}$. sp. fusiforme through stem wounds. (Abstr.) Phytopathology 85:1096.

21. Milliken, G. A., and Johnson, D. E. 1992. Designed Experiments. Vol. 1, Analysis of Messy Data, Chapter 3. Pages 30-34 in: Chapman \& Hall, New York.

22. Mims, C. W., and Doudrick, R. W. 1996. Ultrastructure of spermatia and spermatium ontogeny in the rust fungus Cronartium quercuum f. sp. fusiforme. Can. J. Bot. 74:1050-1057.

23. Powers, H. R., Jr. 1980. Pathogenic variation among single-aeciospore isolates of Cronartium quercuum f. sp. fusiforme. For. Sci. 26:280-282.

24. Powers, H. R., Jr., McClure, J. P., Knight, H 
A., and Dutrow, G. F. 1975. Fusiform rust: forest survey incidence data and financial impact in the South. U.S. Dep. Agric. For. Serv. Res. Pap. SE-127.

25. Schmidt, R. A., and Miller, T. 1995. Inoculum concentration affects pycnial and aecial sporulation on pine seedlings infected by basidiospores of Cronartium quercuum $\mathrm{f}$. sp. fusiforme. (Abstr.) Phytopathology $85: 1142$.

26. Stelzer, H. E., Doudrick, R. L., Kubisiak, T. L., and Nelson, C. D. 1997. Deviation of host and pathogen genotypes in the fusiform rust pathosystem on slash pine using a complimentary genetic model and diallel data. Pages 320-330 in: Proc. 24th South. For. Tree Im- prov. Conf. Orlando, FL.

27. Wilcox, P. L., Amerson, H. V., Kuhlman, E. G., Liu, B. H., O'Malley, D. M., and Sederoff, R. R. 1996. Detection of a major gene for resistance to fusiform rust disease in loblolly pine by genomic mapping. Pages 3859-3864 in: Proc. Natl. Acad. Sci. USA. Vol. 93. Appl. Biol. Sci. 